\begin{tabular}{lc|c|}
\hline Bentham OPEN & The Open Rheumatology Journal & $\begin{array}{l}\text { The Open } \\
\text { Rheummology } \\
\text { lournal }\end{array}$ \\
\hline CrossMark & Content list available at: www.benthamopen.com/TORJ/ & DOI: $10.2174 / 1874312901610010026$ \\
\hline
\end{tabular}

\title{
Is Hearing Impairment Associated with Rheumatoid Arthritis? A Review
}

\author{
Amir Emamifar $^{1, *}$, Kristine Bjoerndal ${ }^{2}$ and Inger M.J. Hansen ${ }^{1}$ \\ ${ }^{I}$ Department of Rheumatology, Odense University Hospital, Svendborg Hospital, Denmark \\ ${ }^{2}$ Department of Otolaryngology Head and Neck Surgery, Odense University Hospital, Denmark
}

\begin{abstract}
:
Background:

Rheumatoid arthritis (RA) is a systemic, inflammatory disease that affects $1 \%$ of the population. The auditory system may be involved during the course of disease; however the association of RA and hearing impairment has not been clearly defined.
\end{abstract}

\section{Objective:}

The objective of this review is to evaluate published clinical reports related to hearing impairment in patients with RA. Furthermore, we discuss possible pathologies and associated factors as well as new treatment modalities.

\section{Method:}

A thorough literature search was performed using available databases including Pubmed, Embase, Cochrane and ComDisDome to cover all relative reports. The following keywords were used: hearing loss, hearing difficulties, hearing disorders, hearing impairment, sensorineural hearing loss, conductive hearing loss, mixed hearing loss, autoimmune hearing loss, drug ototoxicity, drug-induced hearing loss, hearing test, audiometry, auditory dysfunction and rheumatoid arthritis.

\section{Conclusion:}

Based on our review it can be postulated that patients with RA are at higher risk of hearing impairment compared to healthy subjects in their course of the disease. The hearing impairment in RA seems to be a multifactorial condition; however the mechanisms of injury, as well as the relative risk factors, are not completely clear. This review can aid to clarify this condition and is a guide for further evaluation. To the best of our knowledge, this is the first review of hearing impairment in RA.

Keywords: Audiometry, Conductive hearing loss, Hearing impairment, Hearing loss, Mixed hearing loss, Sensorineural hearing loss, Rheumatoid Arthritis.

\section{INTRODUCTION}

Rheumatoid arthritis (RA) is a chronic, inflammatory disease that affects $1 \%$ of the population [1]. Despite its cardinal articular and periarticular features, RA can involve other organs including heart, lung, skin, and eye [2]. In the same way, the auditory system can be affected by a variety of pathologies in the course of disease [3]. There is a wide variation in the reported prevalence of different types of hearing loss in RA patients. Sensorineural hearing loss (SNHL) is the most common type of hearing impairment in RA patients ranging from $25 \%$ to $72 \%$ [3]. Conductive hearing loss (CHL) and mixed hearing loss (MHL) have also been reported less frequently [2, 4, 5]. The objective of this review is to discuss recent findings on the pathology and associated factors of hearing impairment in RA as well as its management.

\footnotetext{
* Address correspondence to this author at the Department of Rheumatology, Odense University Hospital, Svendborg Hospital, Denmark; Tel: +4551670948; Fax: +45 63202282; Email: amir.emamifar@rsyd.dk
} 


\section{METHOD}

A comprehensive search of Pubmed, Embase, Cochrane and ComDisDome databases was performed to cover all relative articles. The following keywords were used: hearing loss, hearing difficulties, hearing disorders, hearing impairment, sensorineural hearing loss, conductive hearing loss, mixed hearing loss, autoimmune hearing loss, drug ototoxicity, drug-induced hearing loss, hearing test, audiometry, auditory dysfunction, rheumatoid arthritis.

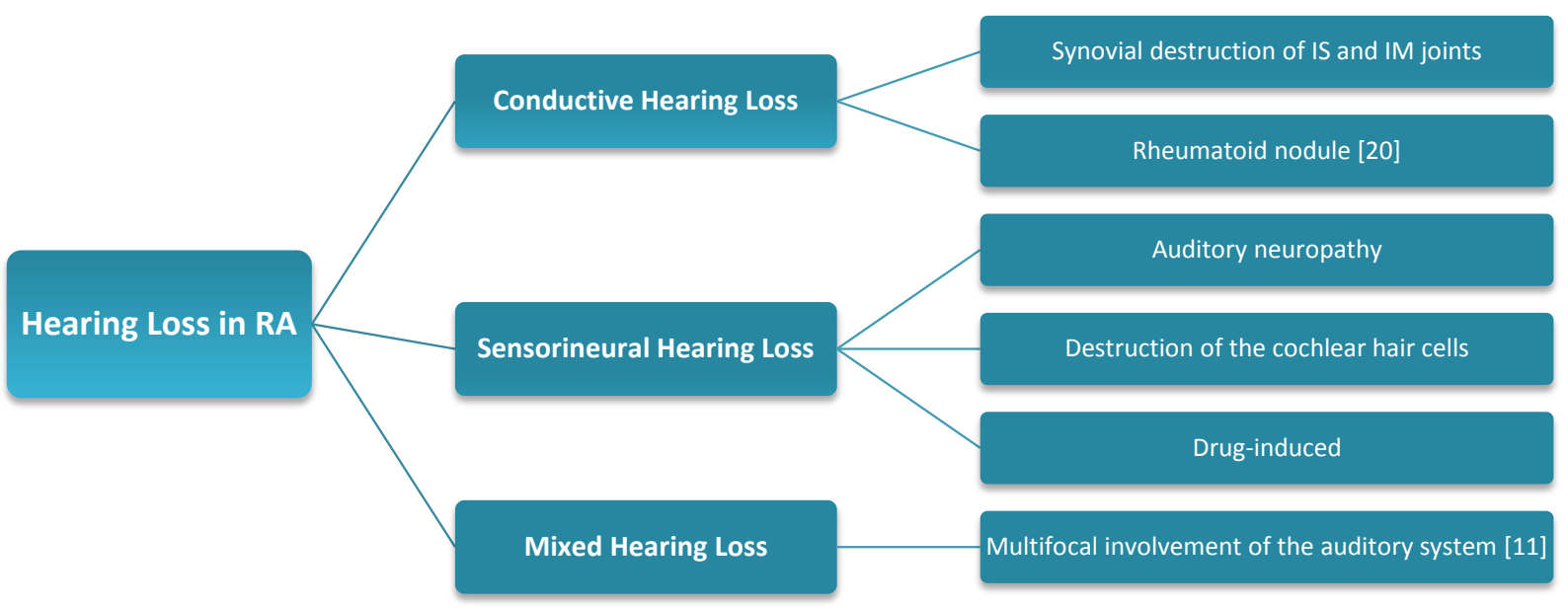

Fig. (1). Different pathologies of hearing impairment in Rheumatoid Arthritis. (Data were extracted from references 2, 4, 9-15, 20)

\section{PATHOLOGY}

A number of possible pathologies have been described by previous studies mainly as follows (Fig. 1):

1. Synovial destruction of incudostapedial (IS) and incudomalleolar (IM) joints by an inflammatory process. (Fig. 2) As IM and IS joints are true diarthroses, they may consequently be involved in RA, like any other joints in the body. This may cause no clinical symptoms since these two joints are functionally fixed during sound transmission [2, 4].

2. Rheumatoid nodules are the most prevalent extra-articular manifestation in RA patients that may present in different locations, however commonly found subcutaneously at points of pressure. Various ear nose throat sites including pharynx, larynx and nose as well as the ears may be affected. Treatment with methotrexate and possibly tumor necrosis factor (TNF) inhibitors may cause rheumatoid nodules or aggravate the tendency to development [6 - 8].

3. Auditory neuropathy due to a probable vasculitis as a part of mononeuritis multiplex.

4. Destruction of the cochlear hair cells, or the inner ear due to immune complex deposition.

5. Drug-induced ototoxicity: Certain kind of drugs including salicylates, non-steroidal anti-inflammatory drugs (NSAIDS), antimalarial and some other disease-modifying antirheumatic drugs (DMARDS) can affect the auditory system [4, 9 - 15].

- Tinnitus, loss of absolute acoustic sensitivity and alterations of perceived sounds are the most frequent side effects of large doses of salicylates. Symptoms develop shortly after treatment initiation, fluctuating during the treatment, and are generally reversible [16].

- Hydroxychloroquine [17] and chloroquine [18] are associated with variable injuries to the cochlear sensory hair cells and a decrease in neuronal population and supporting structures as well as atrophy of stria vascularis resulting in SNHL. This might be reversible if appropriate treatment with corticosteroids in addition to cessation of the drugs is initiated [18, 19].

Takatsu M, et al. [2] showed that the plasma concentration of interleukin-6 (IL-6), matrix metalloproteinases-3 (MMP-3), MMP-9 and tumor necrosis factor alpha (TNF- $\alpha$ ) were increased in RA patients with accompanying SNHL; however the results were only significant for MMP-3 and IL-6. The authors concluded that the pro-inflammatory cytokines (IL-6) and MMPs may contribute to harm inner ear cells by an oxidative process. 


\section{Anatomy of the Ear}

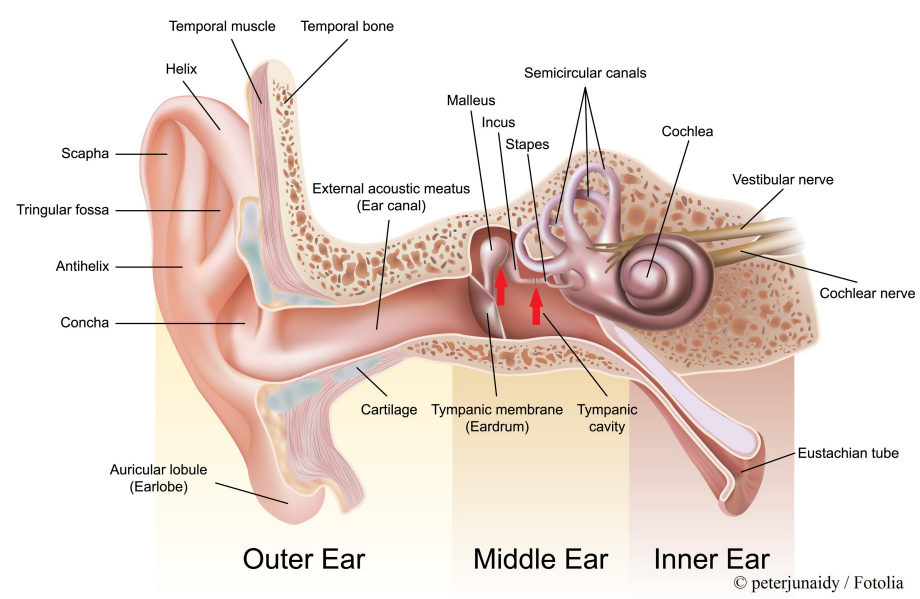

Fig. (2). Incudostapedial (IS) and incudomalleolar (IM) joints showed by red arrows which may be affected by an inflammatory process [21].

\section{ENVIRONMENTAL FACTORS}

\section{- Smoking}

Passive smokers as well as active smokers are at higher risk of hearing impairment. Nicotine-related vasoconstriction and subsequent decrease in the oxygen concentration, due to cigarette smoking, can harm external hair cells and results in declining cochlear function. This can cause SNHL [12].

On the other hand, there is an increased risk of developing rheumatoid nodules and vasculitis in RA patients who are smokers leading to increased rate of both CHL and SNHL [4, 20, 22]. Dikici O, et al. [12] in a recent case-control study of 20 adult patients revealed that there is an inverse relationship between Brinkman Index (= the number of packs of cigarettes smoked per day $\times$ the number of years smoking) and Transiently Evoked Otoacoustic Emissions (TEOAEs), an objective test to determine cochlear function especially outer hair cells, in patients with RA $[23,24]$. The authors suggested that the inner ear vascular system and nutrition may be disturbed as a result of cigarette smoking. Furthermore, there is a strong correlation between smoking and rheumatoid nodules in RA seropositive patients probably due to high production of rheumatoid factor (RF) [25]. We found no literature concerning the relationship between hearing loss and nicotine substitutes e.g. nicotine gum or patches.

\section{- Alcohol}

The auditory system can be affected by long-term exposure to alcohol. This may be due to harmful effects of alcohol on the cochlear function especially outer hair cells which can lead to SNHL [26, 27]. However, we did not find any evidence or study to indicate that RA patients are at a higher level of risk for hearing impairment by consuming alcohol.

\section{- Noise}

Noise can cause a wide spectrum of metabolic and mechanical damages in the cochlea leading to hearing loss. Noise-induced hearing loss is one of the significant causes of acquired hearing loss which is often preventable $[28,29]$. Noise and other factors that affect hearing in healthy individuals are also likely to affect patients with RA, even though no studies were found evaluating these subjects specifically in RA patients.

\section{EFFECTS OF CLINICAL AND LABORATORY FACTORS}

Different variables, summarized in Table 1, may influence the auditory system in RA patients. However, most of the previous studies showed controversial results, partly due to small sample sizes and partly due to methodological differences. Also, the use of various clinical evaluations of RA plus different types of hearing tests intensified this discordance. Elderly Patients and those with long disease duration, active disease, positive RF and increased laboratory values of acute phase reactants as well as rheumatoid nodules are more likely to have hearing impairment $[2,10,12,30$ - 32]. A combination of disease activity indices for instance presence of rheumatoid nodule, swollen and tender joints as well as morning stiffness has been used by earlier studies while recent studies commonly used disease activity score in 28 joints (DAS28) to evaluate disease activity [4]. Dikici O, et al. [12] reported a higher incidence of hearing 
impairment in males, while Poorey VK, et al. [10] mentioned that the incidence of hearing impairment is higher in female patients compared to males. In addition to the above factors, a study by Ozcan M, et al. [9] revealed that there is a positive correlation between hearing loss and Steinbrocker functional classification index [33], which is a scoring system in RA based on the worst joints. It was also shown by Dikici O, et al. that platelet count is associated with hearing impairment, since increase in platelet count and relative hyperviscosity may lead to blood circulation and nutrition disturbances in the inner ear, causing SNHL [12]. In contrast to these findings, results of number of studies demonstrated that there is no correlation between aging [34], sex [2, 34], rheumatoid nodules [4], DAS28 [4], disease duration [2, 4, 10, 32, 34] as well as RF [4] and hearing impairment in RA patients.

Table 1. Different variables are associated to the hearing impairment in patients with Rheumatoid Arthritis. (Data were extracted from references $2,10,12,30-32$ )

\begin{tabular}{|c|}
\hline Age \\
\hline Sex \\
\hline Rheumatoid nodule \\
\hline Disease activity \\
\hline Disease duration \\
\hline Rheumatoid Factor \\
\hline Acute-phase reactants \\
\hline
\end{tabular}

\section{CHARACTERISTICS OF HEARING LOSS}

Different types of hearing tests are available and described in the previous studies mostly pure tone audiometry and Otoacoustic Emissions to accurately diagnose hearing loss in RA patients.

\section{- Pure Tone Audiometry}

Pure tone audiometry is the most frequent test to assess hearing loss, and is performed at frequencies varying from low pitches $250 \mathrm{~Hz}$ to high pitches $8000 \mathrm{~Hz} .250 \mathrm{~Hz}$ and $500 \mathrm{~Hz}$ are low frequencies; $1000 \mathrm{~Hz}$ and 2000 $\mathrm{Hz}$ are middle frequencies; and $4000 \mathrm{~Hz}$ and $8000 \mathrm{~Hz}$ are high frequencies. Extended high frequency audiometry, which tests very high frequencies ranging from 8,000-16,000 Hz, can detect hearing loss at an earlier stage; however it is not commonly used [35, 36]. Earlier evaluations revealed that RA patients have a higher prevalence of hearing loss for all frequencies including low [5], middle [4], high [11] and very high [37].

\section{- Transiently Evoked Otoacoustic Emissions}

TEOAEs test has been used widely to evaluate cochlear function in pediatric and adult populations, since it is easily detectable and can be modified according to age and gender. In this technique sounds emitted in response to acoustic stimuli of very short duration. These sounds are produced by healthy cochlear systems most probably the outer hair cells, whereas any kind of cochlear dysfunction results in decrease or disappearance of TEOAEs [23]. Various amounts of decreases have been reported in RA patients. However some of these patients had normal hearing representing an early stage of hearing impairment $[4,5,12]$.

\section{MANAGEMENT}

There is no consensus regarding the management of hearing impairment in patients with rheumatoid arthritis. Based on empirical grounds, treatment with oral steroid plus cessation of ototoxic drugs should be initiated [18, 20, 33, 38]. Under special circumstances, intratympanic application of steroids with optimized dosage may result in better response (frequencies over $2000 \mathrm{~Hz}$ ) [38]. Limited data suggest using steroid-sparing agents such as methotrexate and TNF inhibitors (infliximab), separately or in combination with other drugs, that can decrease side effects of long-term corticosteroids $[39,40]$. One study recommended treatment with vasodilators to improve cochlear circulation, when there is a decrease in emission amplitudes. Anti-oxidants for instance sodium salicylate, vitamin E and N-acetyl cysteine may play a protective role for the inner ear [12]. Although hearing impairment may present as a subclinical disease, regular audiometric test and TEOAEs is advisable and can diagnose hearing loss at an early stage [11, 12]. Alternatively, assessment of immunoglobulins, complement and acute phase reagents as well as more specific method (e.g. Western-blot (WB) for anticochlear autoantibodies) clarifies the pathogenesis of the disease and may be a lead to earlier diagnosis [41, 42]. When there is a clinical suspicion of serous otitis, radiographic evaluation of affected ear may be beneficial to diagnose RA nodules [20]. Patients and their families should be aware of the noxious effects of smoking on the inner ear which can deteriorate the condition [12]. As alcohol consumption may deteriorate hearing impairment, reduction or cessation of alcohol use is beneficial [26, 27]. In the CHL and MHL cases, surgical 
intervention may be required to repair the sound conduction mechanism of the middle ear [9]. Ordinarily, hearing impairment in patients with RA can also be managed like other causes of hearing loss in general population. Thus in the presence of irreversible hearing loss, using various types of hearing aids and implantable devices are helpful [43].

\section{CONCLUSION}

Based on our review it can be postulated that patients with RA are at higher risk of hearing impairment compared to healthy subjects in their course of the disease. In spite of wide diversity regarding published results, it is obvious that hearing impairment in RA is a multifactorial disease, since it can be affected by environmental factors (e.g. smoking), and disease characteristics (e.g. rheumatoid nodule) as well as patients characteristic (e.g. age). On the other hand, these factors may affect each other both directly and indirectly. For instance, aging has a direct effect on the duration of the disease, and exposure to environmental factors (e.g. noise and acoustic trauma, smoking, etc.) will be increased with aging of the patients. Furthermore, aging is the most frequent cause of age-related hearing loss (Presbycusis). Another example of this is the effect of sex on hearing impairment, while RA affects most commonly female gender; hearing impairment has a higher prevalence in males in comparison with females resulting in counterbalancing each other's effects $[44,45]$. We think that future research should focus on the different pathologies of hearing impairment more precisely, since it can be a lead to better treatment options and prevent further morbidities in RA patients. In the future we are going to conduct a meta-analysis to evaluate the effect of RA on audiological tests to limit the effect of the sample size on the results. To the best of our knowledge, this is the first review of hearing impairment in RA.

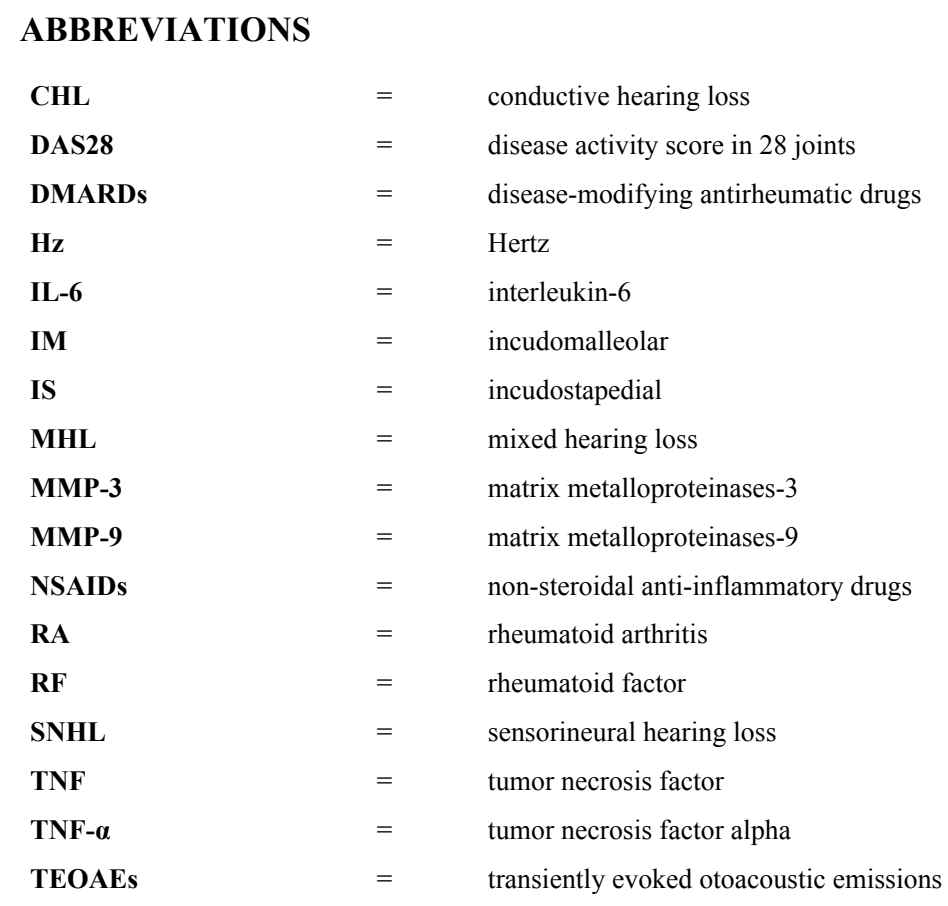

\section{CONFLICT OF INTEREST}

The authors declare that there is no conflict of interest.

\section{ACKNOWLEDGEMENTS}

We thank Steen Fibiger-Dagnæs, subject specialist in audiology and speech pathology at the University Library of Southern Denmark, for his contribution and comments.

\section{REFERENCES}

[1] Özkırış M, Kapusuz Z, Günaydın İ, Kubilay U, Pırtı İ, Saydam L. Does rheumatoid arthritis have an effect on audiovestibular tests? Eur Arch Otorhinolaryngol 2014; 271(6): 1383-7.

[http://dx.doi.org/10.1007/s00405-013-2551-8] [PMID: 23665746]

[2] Takatsu M, Higaki M, Kinoshita H, Mizushima Y, Koizuka I. Ear involvement in patients with rheumatoid arthritis. Otol Neurotol 2005; 26(4): 755-61.

[http://dx.doi.org/10.1097/01.mao.0000178138.19848.bd] [PMID: 16015180] 
[3] Pascual-Ramos V, Contreras-Yáñez I, Rivera-Hoyos P, Enríquez L, Ramírez-Anguiano J. Cumulative disease activity predicts incidental hearing impairment in patients with rheumatoid arthritis (RA). Clin Rheumatol 2014; 33(3): 315-21. [http://dx.doi.org/10.1007/s10067-014-2485-6] [PMID: 24435352]

[4] Murdin L, Patel S, Walmsley J, Yeoh LH. Hearing difficulties are common in patients with rheumatoid arthritis. Clin Rheumatol 2008; 27(5): 637-40. [http://dx.doi.org/10.1007/s10067-007-0802-z] [PMID: 18071780]

[5] Bayazit YA, Yilmaz M, Gunduz B, et al. Distortion product otoacoustic emission findings in Behçet's disease and rheumatoid arthritis. ORL J Otorhinolaryngol Relat Spec 2007; 69(4): 233-8 [http://dx.doi.org/10.1159/000101544] [PMID: 17409782]

[6] Tilstra JS, Lienesch DW. Rheumatoid Nodules. Dermatol Clin 2015; 33(3): 361-71. [http://dx.doi.org/10.1016/j.det.2015.03.004] [PMID: 26143419]

[7] Belloso A, Morar P, Estrach C, Helliwell T, Jackson S. Rheumatoid nodule of the nasal septum. J Laryngol Otol 2001; $115(10)$ : 853-5. [http://dx.doi.org/10.1258/0022215011909170] [PMID: 11668008]

[8] García-Patos V. Rheumatoid nodule. Semin Cutan Med Surg 2007; 26(2): 100-7. [http://dx.doi.org/10.1016/j.sder.2007.02.007] [PMID: 17544962]

[9] Ozcan M, Karakuş MF, Gündüz OH, Tuncel U, Sahin H. Hearing loss and middle ear involvement in rheumatoid arthritis. Rheumatol Int 2002; 22(1): 16-9.

[http://dx.doi.org/10.1007/s00296-002-0185-z] [PMID: 12120906]

[10] Poorey VK, Khatri R. Study of Auditory function in Rheumatoid Arthritis. Indian J Otolaryngol Head Neck Surg 2001; 53(4): 261-3. [PMID: 23119817]

[11] Baradaranfar MH, Doosti A. A survey of relationship between rheumatoid arthritis and hearing disorders. Acta Med Iran 2010; 48(6): 371-3. [PMID: 21287475]

[12] Dikici O, Muluk NB, Tosun AK, Unlüsoy I. Subjective audiological tests and transient evoked otoacoustic emissions in patients with rheumatoid arthritis: analysis of the factors affecting hearing levels. Eur Arch Otorhinolaryngol 2009; 266(11): 1719-26. [http://dx.doi.org/10.1007/s00405-009-0975-y] [PMID: 19360433]

[13] Jung TT, Rhee CK, Lee CS, Park YS, Choi DC. Ototoxicity of salicylate, nonsteroidal antiinflammatory drugs, and quinine. Otolaryngol Clin North Am 1993; 26(5): 791-810. [PMID: 8233489]

[14] Marioni G, Perin N, Tregnaghi A, Bellemo B, Staffieri A, de Filippis C. Progressive bilateral sensorineural hearing loss probably induced by chronic cyclosporin A treatment after renal transplantation for focal glomerulosclerosis. Acta Otolaryngol 2004; 124(5): 603-7. [http://dx.doi.org/10.1080/00016480410016225] [PMID: 15267179]

[15] Toone E, Hayden D, Ellman H. Ototoxicity of chloroquine. Arthritis Rheum 1965; 8: 475-6.

[16] Cazals Y. Auditory sensori-neural alterations induced by salicylate. Prog Neurobiol 2000; 62(6): 583-631 [http://dx.doi.org/10.1016/S0301-0082(00)00027-7] [PMID: 10880852]

[17] Seçkin U, Ozoran K, Ikinciogullari A, Borman P, Bostan EE. Hydroxychloroquine ototoxicity in a patient with rheumatoid arthritis. Rheumatol Int 2000; 19(5): 203-4.

[http://dx.doi.org/10.1007/s002960000054] [PMID: 10984140]

[18] Bortoli R, Santiago M. Chloroquine ototoxicity. Clin Rheumatol 2007; 26(11): 1809-10. [http://dx.doi.org/10.1007/s10067-007-0662-6] [PMID: 17594118]

[19] Mukherjee DK. Chloroquine ototoxicity--a reversible phenomenon? J Laryngol Otol 1979; 93(8): 809-15. [http://dx.doi.org/10.1017/S0022215100087740] [PMID: 490032]

[20] Tavernier L, Ranfaing E. Rheumatoid arthritis involved in the ear drum. Otol Neurotol 2011; 32(1): e5-6. [http://dx.doi.org/10.1097/MAO.0b013e3181d2f039] [PMID: 20142795]

[21] Fotolia. Anatomy of the Ear. File\# 41342727. Available from: https://eu.fotolia.com/id/41342727

[22] Turesson C. Extra-articular rheumatoid arthritis. Curr Opin Rheumatol 2013; 25(3): 360-6. [http://dx.doi.org/10.1097/BOR.0b013e32835f693f] [PMID: 23425964]

[23] Uribe-Escamilla R, Poblano A, Alfaro-Rodríguez A. Transient evoked otoacoustic emissions and cochlear dysfunction. EJENTAS 2013; 14: $195-200$.

[24] Nomura K, Nakao M, Yano E. Hearing loss associated with smoking and occupational noise exposure in a Japanese metal working company. Int Arch Occup Environ Health 2005; 78(3): 178-84 [http://dx.doi.org/10.1007/s00420-005-0604-z] [PMID: 15761747]

[25] Nyhäll-Wåhlin BM, Jacobsson LT, Petersson IF, Turesson C. Smoking is a strong risk factor for rheumatoid nodules in early rheumatoid arthritis. Ann Rheum Dis 2006; 65(5): 601-6. [http://dx.doi.org/10.1136/ard.2005.039172] [PMID: 16166104]

[26] Ribeiro SB, Jacob LC, Alvarenga KdeF, Marques JM, Campêlo RM, Tschoeke SN. Auditory assessment of alcoholics in abstinence. Braz J 
Otorhinolaryngol 2007; 73(4): 452-62.

[http://dx.doi.org/10.1016/S1808-8694(15)30097-5] [PMID: 17923916]

[27] Bellé M, Sartori SdoA, Rossi AG. Alcoholism: effects on the cochleo-vestibular apparatus. Braz J Otorhinolaryngol 2007; 73(1): 110-6. [http://dx.doi.org/10.1016/S1808-8694(15)31132-0] [PMID: 17505609]

[28] Stucken EZ, Hong RS. Noise-induced hearing loss: an occupational medicine perspective. Curr Opin Otolaryngol Head Neck Surg 2014; 22(5): 388-93.

[http://dx.doi.org/10.1097/MOO.0000000000000079] [PMID: 25188429]

[29] Bielefeld EC. Protection from noise-induced hearing loss with Src inhibitors. Drug Discov Today 2015; 20(6): $760-5$. [http://dx.doi.org/10.1016/j.drudis.2015.01.010] [PMID: 25637168]

[30] Pascual-Ramos V, Contreras-Yáñez I, Enríquez L, Valdés S, Ramírez-Anguiano J. Hearing impairment in a tertiary-care-level population of Mexican rheumatoid arthritis patients. J Clin Rheumatol 2012; 18(8): 393-8. [http://dx.doi.org/10.1097/RHU.0b013e31827732d3] [PMID: 23188202]

[31] Goodwill CJ, Lord IJ, Jones RP. Hearing in rheumatoid arthritis. A clinical and audiometric survey. Ann Rheum Dis 1972; $31(3)$ : 170-3. [http://dx.doi.org/10.1136/ard.31.3.170] [PMID: 5032449]

[32] Magaro M, Zoli A, Altomonte L, et al. Sensorineural hearing loss in rheumatoid arthritis. Clin Exp Rheumatol 1990; 8(5): 487-90. [PMID: 2261709]

[33] Steinbrocker O, Traeger CH, Batterman RC. Therapeutic criteria in rheumatoid arthritis. J Am Med Assoc 1949; 140(8): 659-62. [http://dx.doi.org/10.1001/jama.1949.02900430001001] [PMID: 18150288]

[34] Kastanioudakis I, Skevas A, Danielidis V, Tsiakou E, Drosos AA, Moustopoulos MH. Inner ear involvement in rheumatoid arthritis: a prospective clinical study. J Laryngol Otol 1995; 109(8): 713-8. [http://dx.doi.org/10.1017/S0022215100131135] [PMID: 7561491]

[35] Mehrparvar AH, Mirmohammadi SJ, Davari MH, et al. Conventional audiometry, extended high-frequency audiometry, and DPOAE for early diagnosis of NIHL. Iran Red Crescent Med J 2014; 16(1): e9628. [http://dx.doi.org/10.5812/ircmj.9628] [PMID: 24719719]

[36] Müller U, Barr-Gillespie PG. New treatment options for hearing loss. Nat Rev Drug Discov 2015; 14(5): $346-65$. [http://dx.doi.org/10.1038/nrd4533] [PMID: 25792261]

[37] Treviño-González JL, Villegas-González MJ, Muñoz-Maldonado GE, Montero-Cantu CA, Nava-Zavala AH, Garza-Elizondo MA. [Subclinical sensorineural hearing loss in female patients with rheumatoid arthritis]. Cir Cir 2015; 83(5): 364-70. [http://dx.doi.org/ 10.1016/j.circir.2015.05.026] [PMID: 26141107]

[38] Milisavljevic D, Stankovic I, Stankovic M. Is the treatment of hearing loss in rheumatoid arthritis effective? Hippokratia 2014; $18(3)$ : 288. [PMID: 25694769]

[39] Street I, Jobanputra P, Proops DW. Etanercept, a tumour necrosis factor alpha receptor antagonist, and methotrexate in acute sensorineural hearing loss. J Laryngol Otol 2006; 120(12): 1064-6. [http://dx.doi.org/10.1017/S0022215106002593] [PMID: 17040588]

[40] Gazeau P, Saraux A, Devauchelle-Pensec V, Cornec D. Long-term efficacy of infliximab in autoimmune sensorineural hearing loss associated with rheumatoid arthritis. Rheumatology (Oxford) 2014; 53(9): 1715-6. [http://dx.doi.org/10.1093/rheumatology/keu025] [PMID: 24625506]

[41] García Callejo FJ, Conill Tobías N, Muñoz Fernández N, de Paula Vernetta C, Alonso Castañeira I, Marco Algarra J. [Hearing impairment in patients with rheumatoid arthritis]. Acta Otorrinolaringol Esp 2007; 58(6): 232-8. [http://dx.doi.org/10.1016/S2173-5735(07)70341-1] [PMID: 17663942]

[42] García Callejo FJ, Corts J, de Paula Vernetta C, Laporta P, Ramírez Sabio J, Marco Algarra J. Cormobidity of sensorineural hearing loss and other autoimmune diseases. Usefulness of laboratory tests. Acta Otorrinolaringol Esp 2006; 57(1): 28-33. [PMID: 16503030]

[43] Stokroos RJ, George EL. [Hearing implants]. Ned Tijdschr Geneeskd 2013; 157(51): A6927. [PMID: 24345362]

[44] Kvien TK, Uhlig T, Ødegård S, Heiberg MS. Epidemiological aspects of rheumatoid arthritis: the sex ratio. Ann N Y Acad Sci 2006; 1069: 212-22. [http://dx.doi.org/10.1196/annals.1351.019] [PMID: 16855148]

[45] Karlsmose B, Lauritzen T, Parving A. Prevalence of hearing impairment and subjective hearing problems in a rural Danish population aged 31-50 years. Br J Audiol 1999; 33(6): 395-402. [http://dx.doi.org/10.3109/03005364000000107] [PMID: 10656600] Accepted: January 19,2016

(C) Emamifar et al.; Licensee Bentham Open

This is an open access article licensed under the terms of the Creative Commons Attribution-Non-Commercial 4.0 International Public License (CC BY-NC 4.0) (https://creativecommons.org/licenses/by-nc/4.0/legalcode), which permits unrestricted, non-commercial use, distribution and reproduction in any medium, provided the work is properly cited. 